Gut, 1978, 19, 787-793

\title{
Treatment of encephalopathy during fulminant hepatic failure by haemodialysis with high permeability membrane
}

\author{
J. DENIS, P. OPOLON1, V. NUSINOVICI, A. GRANGER, AND F. DARNIS
}

From the Centre Hospitalo-Universitaire St. Antoine, Paris, and the Rhône-Poulenc Industries Research Centre, Vitry, France

SUMMARY Forty-one patients with fulminant hepatic failure and coma underwent 180 periods of haemodialysis with polyacrylonitrile membrane (AN $69 \mathrm{HD}$ ). Hepatic failure was due to viral hepatitis in 40 and drugs in one. Total recovery of consciousness occurred in 17 patients $(43.6 \%)$, and partial in seven $(17.9 \%$ )-that is, an overall figure of $61.5 \%$. Regain of consciousness was not related to liver regeneration as assessed by levels of factor $\mathrm{V}$ and hepatocyte volume fraction. At the time of the first haemodialysis, neurological status was significantly impaired in the patients who could not be aroused. Mean duration of coma grade IV averaged $6 \cdot 1 \pm 4.3$ days and mean duration of illness until death or decerebration $8.6 \pm 8.3$ days. Of the 17 patients who totally regained consciousness, nine recovered and eight died (three from intercurrent complications and five with no liver regeneration).

Although some recent experimental results show that hepatic regeneration may be enhanced by the synergistic action of insulin and glucagon (Farivar et al., 1976), no therapy for inducing restoration of liver cell mass is yet available in man. On the other hand, during fulminant hepatic failure cerebral death is responsible for $50 \%$ of deaths (Ware et al., 1971; Gazzard et al., 1975; Nusinovici et al., 1977), even when liver regeneration occurs (Rueff and Benhamou, 1973; Scotto et al., 1973; Opolon et al., 1975). Hence, the need for artificial support to prevent irreversible brain damage has led recently to numerous experimental and clinical trials: interhuman (Muller et al., 1971; Sicot et al., 1972; Rueff et al., 1974) or heterologous cross-circulation (Saunders et al., 1968; Hume et al., 1969), total body washout (Klebanoff et $a l .$, 1972), and charcoal haemoperfusion (Gazzard $e t$ al., 1974). Previous laboratory experiments showed that haemodialysis with high permeability polyacrylonitrile membrane (AN 69) allowed progressive consciousness and EEG enhancement in $60 \%$ of comatose animals after acute liver ischaemia (Opolon et al., 1976a). Dialytic permeability of such

\footnotetext{
${ }^{1}$ Address for reprint requests: P. Opolon, CHU SaintAntoine, 184 rue du Faubourg Saint-Antoine, 75012 Paris, France.
}

Received for publication 22 March 1978 a membrane in the 5000 daltons range is 10 -fold higher than Cuprophan (Sausse et al., 1974). More recently, changes in brain neurotransmitters observed during experimental liver coma appeared to be corrected after AN 69 haemodialysis (Opolon et al., 1976b; Bloch et al., 1978). Preliminary trials of AN 69 haemodialysis in fulminant hepatic failure showed a significant enhancement of the neurological status (Opolon et al., 1975; 1976b). This paper reports the results of such treatment in a series of 41 patients with coma and acute liver failure.

\section{Methods}

\section{PATIENTS}

Forty-one patients with coma and fulminant hepatic failure (FHF) were admitted to intensive care unit from November 1974 to March 1977. They were treated by haemodialysis with AN 69 membrane and underwent 180 periods of haemodialysis. Nineteen of the patients were male $((43.6 \%)$ and 22 female $(53.7 \%)$. Mean age averaged 39 years \pm SD 16 (range 14-70 years). Viral hepatitis type B was confirmed in 20 cases by positive HBsAg. Electroimmunodiffusion titres ranging from $1 / 8$ to $1 / 250$ allowed complete subtyping in eight patients (ayw in seven, adw in one). Two more cases with $1 / 4 \mathrm{HBsAg}$ titre were determined as ay. Four HBsAg positive patients 
become anti HBs positive in a few days at a level ranging from $13 \%$ to $25 \%$ (RIA) while remaining HBsAg positive. Six other patients were HBsAg negative but had anti HBs levels ranging from $15 \%$ to $80 \%$ (RIA). Another patient who had been treated with isoniazid and rifampicin for one year developed liver failure after undergoing halothane anaesthesia. In the 13 other $\mathrm{HBsAg}$ and anti-HBs negative patients, the clinical history was consistent with type A viral hepatitis. The interval between the onset of jaundice and coma ranged from 0 to 64 days (mean $10 \cdot 6 \pm$ SD 13 days).

\section{EEG RECORDINGS}

The levels of consciousness and EEG recordings were classified into the five grades previously described (Opolon et al., 1969, 1976b). These are summarised in Table 1. Neurological status was evaluated every eight hours. Continuous EEG recordings were obtained in 15 patients who underwent 55 periods of haemodialysis. EEG readings were analysed by an independent observer without knowledge of the clinical conditions of the patients. On admission
(Figure) three patients showed signs of grade III coma, and 36 grade IV coma. Two patients showed signs of grade $\mathrm{V}$ coma (Table 1) and are therefore excluded from the following results.

\section{BIOCHEMICAL MEASUREMENTS}

Daily biochemical measurements were carried out for: alanine aminotransferase and aspartate aminotransferase transaminases, ammonia (Berthelot colorimetric method); coagulation studies included thromboplastin time, factors II, V, VII + X, fibrinogen, euglobulin lysis time, ethanol gelation test, platelets count, FDP. In addition, measurements were made of arterial blood gases, blood and urinary glucose, urea, electrolytes and blood creatinine, amylase, calcium and phophorus, total proteins and electrophoresis, blood volume ( $\mathrm{Cr}^{51}$ labelled red cells). Before and after each haemodialysis period, the following measurements were carried out in arterial blood and dialysate: ammonia in all patients, amino-acids (AA) in 20 patients (by anion exchange resin chromatography with a Technicon autoanalyser).

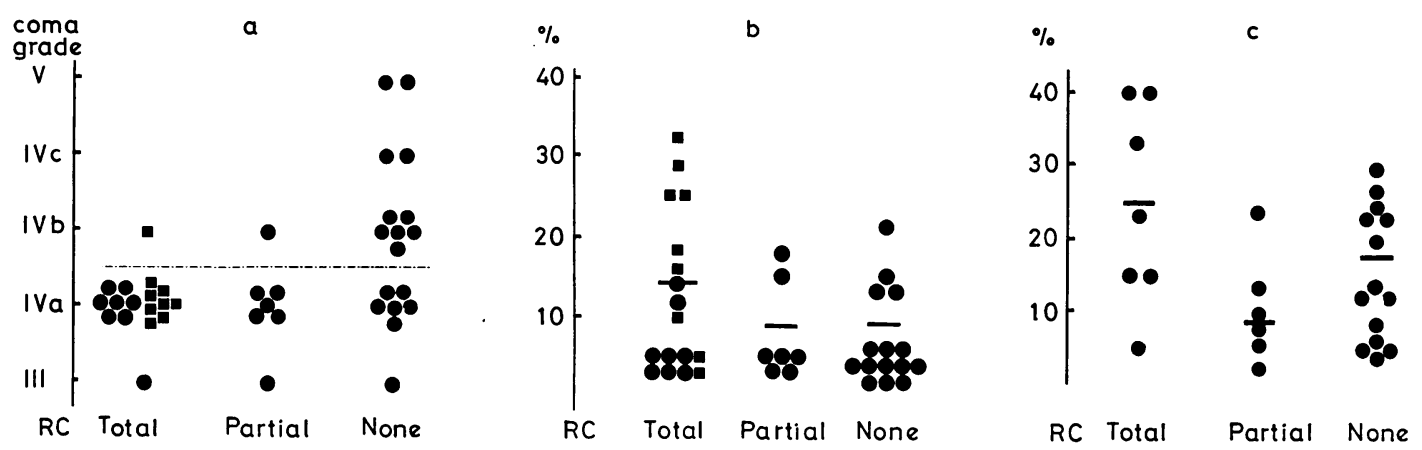

Figure (a) Grade of clinical coma at the time of the first haemodialysis; (b) minimal value of factor $V$ during the course of illness; (c) hepatocyte volume fraction in patients with or without recovery of consciousness $(R C)$.

Survival. Death.

Table 1 Details of coma and EEG grades

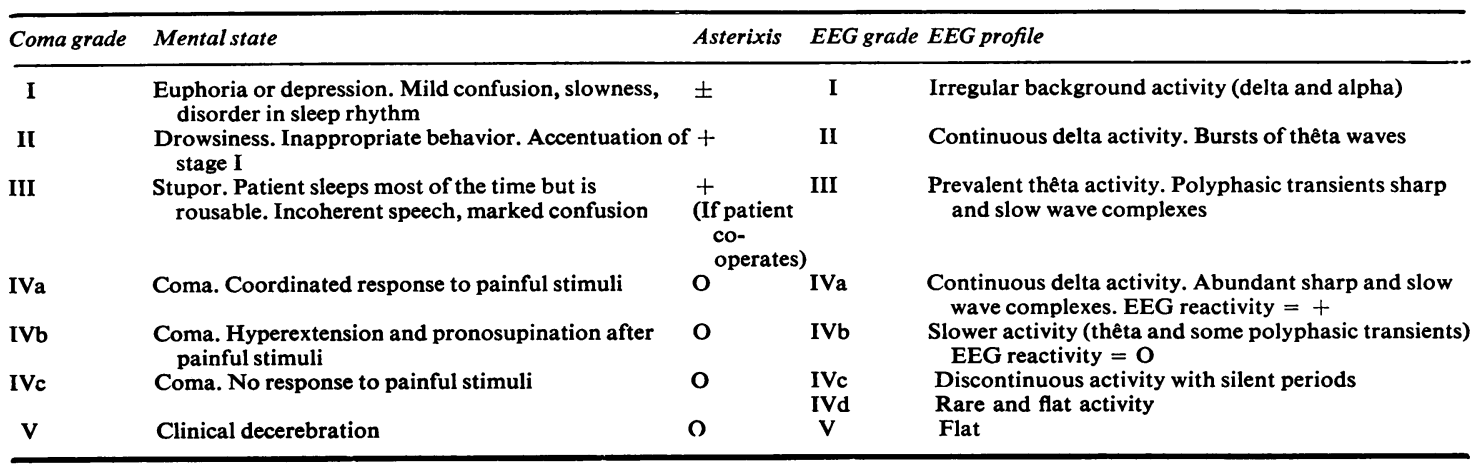


HEPATOCYTE VOLUME FRACTION

HVF (normal value $85 \pm$ SD $5 \%$ ) was estimated by stereological counting (Caroli et al., 1971; Scotto et al., 1973) on immediate pre- or post-mortem liver biopsy in 30 patients. Total necropsy was carried out in 18 patients.

All patients received full supportive measures including continuous intravenous glucose infusion, intragastric administration of antacids and lactulose (300 ml/day); hypovolaemia was corrected by whole blood, plasma, or packed red-cells infusion. Respiratory assistance was required in 27 cases (six patients required intubation before admission, eight for respiratory arrests, 13 for bronchial stasis). One patient received hydrocortisone hemisuccinate (300 mg daily), and one bêta-1-24-corticotrophin ( $0.75 \mathrm{mg}$ daily). Blood, urine and bronchial aspirations were cultured daily and antibiotics prescribed according to the results.

\section{HAEMODIALYSIS}

A disposable RPO6 haemodialyser (Sausse et al., 1974), with a polyacrylonitrile (AN 69) dialysis membrane, and a closed loop closed batch delivery system was used. Dialysate volume averaged 52:1 for the first 25 patients and 72:1 for the following 16. Sterile dialysate buffered with acetate was used. Blood flowrate monitored by an ultrasonic flowmeter averaged 200-400 $\mathrm{ml} / \mathrm{min}$, dialysate flow-rate $500-1000 \mathrm{ml} /$ min, and ultrafiltration rate (balanced by intravenous saline infusion) $100-300 \mathrm{ml} / \mathrm{h}$. A forearm Scribner shunt was used in all but three patients who underwent venovenous haemodialysis. Local heparinisation (40-80 mg for each haemodialysis) without protamine was carried out. Haemodialysis started six to 48 hours after the onset of coma (usually 12 to 24 hours). Haemodialysis periods lasted for three to four hours and were carried out until consciousness levels improved or until signs of grade $\mathrm{V}$ coma developed or the patient died. The first 30 patients underwent haemodialysis daily or every other day. In the following 11 , haemodialysis was performed once to three times a day according to the neurological status.

Statistical analysis of results was carried out using the Student-Fischer $t$ test and $\chi^{2}$ test.

\section{Results}

\section{CLINICAL RESULTS}

\section{Effects on consciousness and EEG}

Thirty-eight patients in grade III-IVc (Table 1) coma on admission underwent 164 haemodialysis periods. Continuous EEG recording in 15 patients during 55 haemodialysis periods showed improvement in 29 $(52.7 \%)$, no change in $24(43.6 \%)$, and impairment in two. Total recovery of consciousness (coma grade
I or 0$)$ occurred after 28 haemodialysis periods $(17 \cdot 1 \%)$. Partial recovery of consciousness (from grade IV to grade III or II) followed 22 haemodialysis periods $(13.5 \%)$. Slight changes in clinical coma grade were observed during and after the other 114 haemodialysis periods. Coma was fully reversible during the course of the illness in 17 patients $(43 \cdot 6 \%)$ and partially in seven others $(17.9 \%)$-that is, improvement of consciousness in a total of $61.5 \%$ of the patients. Repeated partial or total recovery of consciousness with relapses of coma betwen haemodialysis periods occurred in eight patients: four of these showed no evidence of liver regeneration and subsequently died; in the four others, liver regeneration occurred; three of these recovered and one died of renal failure and shock. Improvement in conscious levels was not related to the age of patients, HVF (Figure), or with the factor $V$ level at the moment of the first haemodialysis or at its lowest value during the course of illness (Figure). The minimal value of factor $\mathrm{V}$ during illness (Figure) was significantly lower $(P<0.02)$ in patients who required consciousness and subsequently died $(8 \cdot 7 \% \pm 0.9 \%)$ than in survivors $(18 \cdot 7 \% \pm 3 \cdot 1 \%)$. Coma grade on admission (Figure) was significantly deeper $(P<0.05)$ in patients who did not recover consciousness: $46 \cdot 7 \%$ were in coma grade IVb-IVc as compared to $8.3 \%$ in patients who regained consciousness either totally or partially.

\section{Clinical course and long-term follow-up}

Of the 15 patients who never recovered consciousness, only one showed histological signs of liver regeneration (HVF $=45 \%$ ) and this patient died following cerebral coning. Fatal outcome in the other patients was related to septicaemia (one), gastrointestinal bleeding (two), pancreatitis (two), cardiogenic shock (two), and in the remaining patients there was a progressive flattening of EEG leading to clinical and electrical brain death (decerebration). None of the seven patients with partial recovery of consciousness showed histological signs of liver regeneration at the moment of death, which occurred after acute pancreatitis (one), decerebration (two), and acute circulatory failure (four). Eight patients who totally regained consciousness subsequently died. Evidence of liver regeneration (HVF $\geqslant 34 \%$ ) was observed in three, whose death was not directly related to liver failure: ischaemic colitis at the eighth day, gastrointestinal bleeding on the 25th day and renal failure and shock on the seventh day. HVF was not measured in a patient who died of septicaemia in the 14th day of illness. The four other patients died without evidence of liver regeneration $(5 \% \leqslant$ HVF $\leqslant$ $23 \%$ ). Their illness was characterised by a previous clinical story of progressive jaundice and decrease of 
clotting factors, persisting high levels of transaminases over periods ranging from 24 to 64 days before the onset of coma. One of them completely recovered consciousness for four days and subsequently died of gastrointestinal bleeding on the seventh day. The other three repeatedly regained consciousness after each haemodialysis period and died respectively of peritonitis (after surgery for bleeding ulcer) on the 40th day, irreversible coma and septic shock on the 20th day, and on the 15th day with a flat EEG. Nine of the $39(23.1 \%)$ patients recovered from the acute episode of liver failure. In one case, five episodes of cardiac arrest occurred within the first five days of coma, leading to cerebral anoxia; although EEG recordings and liver function improved, he was left with major neurological sequelae and died two months after discharge of pneumonia. In the other eight cases, brain function was fully restored. Liver function tests returned to normal in six cases; however, one patient was still HBsAg positive nine months later and refused to undergo a liver biopsy. One patient was lost to follow-up after discharge. Another developed mild abnormalities of liver function and had histological evidence of chronic active hepatitis on the follow-up liver biopsy. He was treated with prednisone $(15 \mathrm{mg}$ daily) and azathioprine ( $50 \mathrm{mg}$ daily) from the eighth to 15th month after discharge, after which treatment was discontinued when a new liver biopsy showed a normal histological picture. This patient remained HBsAg and anti-HBs negative throughout this whole period. One patient who was in the eighth month of pregnancy on admission was delivered of a normal baby by caesarean section and mother and child are now alive and well.

\section{Side-effects}

Systolic blood pressure remained stable during 160 haemodialysis periods $(88.9 \%)$. Hypotension (systolic $\mathrm{BP}<80 \mathrm{mmHg}$ ) occurred in 15 patients during the course of 20 haemodialysis periods $(11.1 \%)$. In six instances hypotension was promptly corrected by plasma volume expansion and, in one, blood pressure spontaneously returned to normal: Irreversible hypotension during the course of the 13 other haemodialysis periods occurred in patients either with pre-existing shock (two) or showing evidence of cardiac failure (three), either with very deep coma and an .EEG grading of greater than IVc or IVd (eight). Blood electrolytes and acid-base balance remained stable. Clotting factors levels and platelet counts did not significantly decrease during haemodialysis.

\section{Anatomopathological findings}

Necropsy was carried out in 18 patients. Gastric ulceration or haemorrhagic gastritis were found in five $(26.3 \%)$, of whom three died of gastrointestinal bleeding. Examination of the brain in 13 cases showed cerebral oedema in five $(38.5 \%)$ with temporal hernia in one. Pancreatic cytosteatonecrosis was found in six cases, but was considered to be responsible for death in only two patients. The clinical diagnosis of ischaemic colitis was confirmed at necropsy in one patient.

\section{BIOCHEMICAL RESULTS}

Arterial blood ammonia level (Table 2) fell significantly in all patients during haemodialysis. Both the arterial blood levels and dialysate ammonia contents were significantly higher in patients who did not regain consciousness.

Plasma amino-acids were measured before and after haemodialysis in 10 patients who totally regained consciousness (34 haemodialysis periods) and 10 who did not ( 25 haemodialysis periods). The branched chain amino acids were slightly decreased in all patients (Valine $=0.19 \pm$ SD $0.12 \mathrm{mc} \mathrm{mol} / \mathrm{ml}$; leucine $=0.12 \pm \mathrm{SD} 0.06 \mathrm{mc} \mathrm{mol} / \mathrm{ml}$; isoleucine $=$ $0.06 \pm \mathrm{SD} 0.03 \mathrm{mc} \mathrm{mol} / \mathrm{ml}$ ) and did not change after haemodialysis periods (valine $=0.19 \pm$ SD $0.11 \mathrm{mc}$ $\mathrm{mol} / \mathrm{ml}$; leucine $=0.14 \pm \mathrm{SD} 0.07 \mathrm{mc} \mathrm{mol} / \mathrm{ml}$; isoleucine $=0.06 \pm \mathrm{SD} 0.04 \mathrm{mc} \mathrm{mol} / \mathrm{ml}$ ).

All unbranched amino acid levels were increased in all patients before haemodialysis and the values were higher in those patients who did not subsequently regain consciousness. In all patients blood levels significantly fell after haemodialysis, irrespective of the effect of haemodialysis on conscious levels. Amino-acids dialysate contents calculated from dialysate concentration at the end of each haemodialysis period and dialysate volume were

Table $2 \quad \mathrm{NH}_{4}$ blood levels and dialysate content

\begin{tabular}{|c|c|c|c|}
\hline & \multicolumn{2}{|c|}{ No recovery of consciousness } & \multirow{2}{*}{$\frac{\text { Recovery of consciousness }}{24}$} \\
\hline $\begin{array}{l}\text { Patients (no.) } \\
\text { Haemodialysis (no.) }\end{array}$ & $\begin{array}{l}15 \\
46\end{array}$ & & \\
\hline \multicolumn{4}{|l|}{$\begin{array}{l}\text { Haemodialysis (no.) } \\
\text { Blood }(\mu \mathrm{g} \%)\end{array}$} \\
\hline Before HD & $\begin{array}{l}224.8 \pm 90.2 \\
<0.01\end{array}$ & $<0.001$ & $\begin{array}{l}166.3 \pm 64.5 \\
<0.001\end{array}$ \\
\hline $\begin{array}{c}\text { After HD } \\
\text { Dialysate (mg) }\end{array}$ & $\begin{aligned} 173 \cdot 6 & \pm 69 \\
49 \cdot 3 & \pm 27 \cdot 3\end{aligned}$ & $\begin{array}{l}<0.001 \\
<0.001\end{array}$ & $\begin{array}{r}127 \cdot 2 \pm 51 \cdot 1 \\
33 \cdot 7 \pm 23 \cdot 2\end{array}$ \\
\hline
\end{tabular}


Table 3 Amino acid dialysate content*

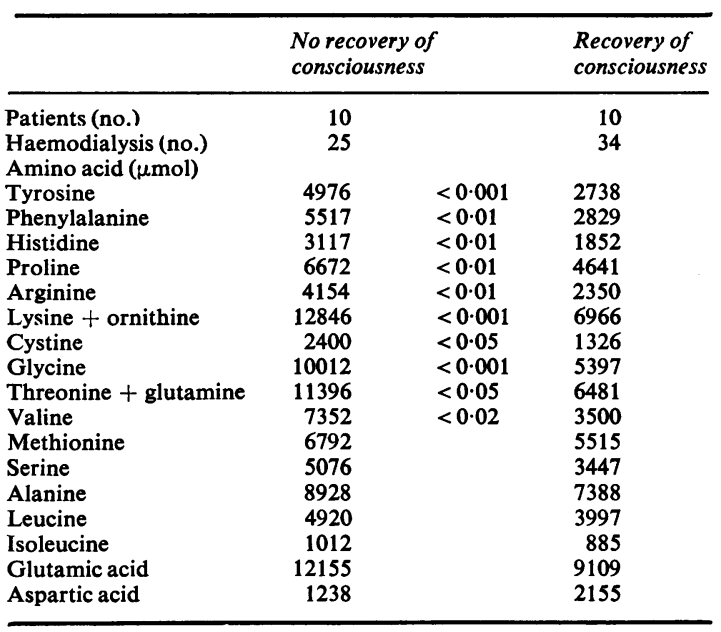

*Mean value of all dialysate pools in both groups of patients

significantly higher for 10 amino acids (Table 3 ) in patients who did not recover consciousness. Serial measurements either in plasma or dialysate, although showing higher values in patients who did not recover consciousness, did not allow us to predict neurological enhancement or deterioration. The molar ratio valine + leucine + isoleucine/phenylalanine + tyrosine before haemodialysis was significantly higher $(P<0.05)$ in patients who recovered consciousness $(0.89)$ than in those who did not $(0.60)$ and was not corrected after haemodialysis.

\section{Discussion}

Results on consciousness obtained with AN 69 haemodialysis confirm preliminary studies in animals (Opolon et al., 1976b) and man (Opolon et al., 1975, 1976b). In a previous series of 117 similar patients concerning the aetiology of fulminant hepatic failure, sex, age, biochemical findings, coma, and EEG grades (Nusinovici et al., 1977) treated in this unit by conservative intensive care without any extracorporeal assistance, only $26(22 \cdot 2 \%)$ totally regained consciousness and none partially regained consciousness. In the 96 cases with fatal outcome, mean duration of coma grade IV and mean duration of illness until death or decerebration were similar: respectively $4.3 \pm 2.8$ days (1-13) and $4.4 \pm 3.3$ days (1-16). Of the 39 patients treated with AN 69 haemodialysis in the present study, $17(43.6 \%)$ fully regained consciousness $(P<0.02)$ and seven $(17.9 \%)$ partially regained consciousness; mean duration of coma in the 30 patients who died averaged $6 \cdot 1 \pm 4 \cdot 3$ days $(1-19)(P<0.02)$ and mean duration of illness until death or decerebration $8.6 \pm 8 \cdot 3$ days $(1-40$ days) $(\mathrm{P}<0.001)$. With supportive therapy alone, transient total recovery of consciousness was observed only in five out of 96 patients who died $(5.2 \%)$ and always associated with an increase in factor V levels and HVF ( $\geqslant 45 \%$ ). After AN 69 haemodialysis, eight of the 30 patients who died $(26.6 \%)$ transiently regained complete consciousness $(P<0.01)$, only three of them showed histological evidence of liver regeneration. Moreover, none of the seven cases who transiently recovered partial consciousness showed biochemical histological evidence of liver regeneration. Despite these hopeful results on consciousness, AN 69 haemodialysis did not change survival rate: $23.1 \%$ against $17.9 \%$ with supportive intensive care. The King's College liver failure unit (Silk et al., 1977; Silk and Williams, 1978) reported rather different results regarding consciousness and survival. In a series of 65 patients treated by AN 69 haemodialysis, only one out of $21(4.8 \%)$ who recovered consciousness subsequently died, compared with eight out of $17(47 \cdot 1 \%)$ in our series. The overall survival rate of the King's series was $30.8 \%$. Liver failure was due to paracetamol overdose in 29 cases $(44.6 \%)$ or miscellaneous diseases in five cases $(7.7 \%)$ with a $35.3 \%$ survival rate in these 34 patients. The 31 other patients $(47.7 \%$ in 65 patients) were reported as fulminant viral hepatitis (without any details on $\mathrm{HBsAg}$ ) and had a $25.8 \%$ survival rate. This latter figure is very close to the $21 \%$ survival rate observed in the 38 patients with fulminant viral hepatitis reported in this study. In our series, no difference regarding sex, regaining of consciousness, duration of coma grade IV and of course of illness, or numbers of haemodialysis periods was found between HBs positive and HBs negative patients. HBs positive patients were younger $(34 \pm 14.5$ years versus $47.1 \pm 15.7$ years $-P<0.05)$ with a lower survival rate $(17 \cdot 4 \%$ versus $31 \cdot 2 \%)$. This much higher incidence of viral hepatitis in our series may account for the higher mortality rate in our series compared to the results of the King's College group.

In previously published experiments (Bloch et al., 1978), simultaneous measurements of plasma and brain amino acid levels in animals at an early stage after liver devascularisation showed a net uptake into brain of many amino acids. No information is available about brain amino acid concentrations in patients with fulminant hepatic failure during life, and studies of plasma amino acid levels have usually been carried out at a relatively advanced stage of the metabolic encephalopathy. Hence variations in overall or sequential plasma amino acid levels seem to correlate better with the severity of hepatic necrosis (Rosen et al., 1977) than with specific changes 
relating to hepatic encephalopathy (Fischer et al., 1975; Fischer and Baldessarini, 1976; Record et al., 1976). In previous experimental work (Opolon et al., 1976b), as well as in this clinical trial, the lack of relation between recovery of consciousness and a specific variation of any water-soluble low molecular weight substance allows one to suppose that watersoluble middle molecular weight molecule(s) may be involved in the metabolic pathways of acute hepatic encephalopathy.

The beneficial effect of AN 69 haemodialysis appears to be limited to a restricted number of patients as well to a rather short period of time. Two factors may be responsible for these limits: first, even when patients are referred to intensive care units at the initial stage of coma, metabolic disorders in the brain are likely to have occurred up to 36 to 72 hours earlier. Hence any extracorporeal detoxification system will have to remove the previously accumulated pool plus the daily production of toxic substances. Second, if middle molecules are involved in the pathogenesis of acute liver encephalopathy, more efficient techniques than haemodialysis are required. Thus the next step in extracorporeal liver assistance during fulminant hepatic failure should be (1) a better tactical approach with earlier treatment-that is, at coma grade II or III level-for longer periods of time - that is, continuous assistance until recovery of consciousness; (2) technical enhancement of techniques for removing water-soluble middle molecules and/or protein-bound substances.

The authors wish to acknowledge the nursing and clinical staff (ICU, Service du Pr F. Darnis, Hôpital Saint-Antoine, 75012 Paris); Dr P. Bloch, Dr D. Gallot, and Dr L. Loygue for putting the Schribner's shunt on the patients; the biochemistry staff (service du Pr J. Polonowski and du Pr H. Renault); Dr A. Robert for monitoring haemostasis; and the staff of Centre de Transfusion Sanguine (53 Bd Diderot, 75012 Paris).

\section{References}

Bloch, P., Delorme, M. L., Rapin, J. R., Boschat, M., and Opolon, P. (1978). Reversible modifications of brain neurotransmitters in experimental acute hepatic coma. Surgery, Gynecology and Obstetrics, 146, 551-558.

Farivar, M., Wands, J. R., Isselbacher, K. J., and Bucher, N. L. R. (1976). Effect of insulin and glucagon on fulminant murine hepatitis. New England Journal of Medicine, 295, 1517-1519.

Fischer, J. E., and Baldessarini, R. J. (1976). Pathogenesis and therapy of hepatic coma. Progress in Liver Diseases, 5, 363397.

Fischer, J. E., Funovics, J. M., Aguirre, A., James, J. H., Keane, J. M., Wesdorp, R. I. C., Yoshimura, N., and Westman, T. (1975). The role of plasma amino-acids in hepatic encephalopathy. Surgery, 78, 276-290.
Gazzard, B. G., Portmann, B., Murray-Lyon, I. M., and Williams, R. (1975). Causes of death in fulminant hepatic failure and relationship to quantitative histological assessment of parenchymal damage. Quarterly Journal of Medicine, 44, 615-626.

Gazzard, B. G., Weston, M. J., Murray-Lyon, I. M., Flax, H., Record, C. O., Portmann, B., Langley, P. G., Dunlop, E. H., Mellon, P. J., Ward, M. B., and Williams, R. (1974). Charcoal haemoperfusion in the treatment of fulminant hepatic failure. Lancet, 1, 1301-1307.

Hume, D. M., Gayle, W. E., Jr., and Williams, G. M. (1969). Cross-circulation of patients in hepatic coma with baboon partners having human blood. Surgery, Gynecology and Obstetrics, 128, 485-517.

Klebanoff, G., Hollander, D., Cosimi, A. B., Stanford, W., and Kemmerer, W. T. (1972). Asanguinous hypothermic total body perfusion (TBW) in the treatment of stage IV hepatic coma. Journal of Surgical Research, 12, 1-7.

Muller, J. M., Guignier, M., Motin, J., Paliard, P., and Debro, J. L. (1971). Notre expérience de la circulation croisée comme méthode d'assistance hépatique dans les insuffisances hépatiques graves aiguës. Annales de Médecine Interne, 122, 581-587.

Nusinovici, V., Crubille, C., Opolon, P., Touboul, J. P., Darnis, F., and Caroli, J. (1977). Hépatites fulminantes avec coma. Revue de 137 cas. I. Complications. Gastroenterologie Clinique et Biologique, 1, 861-873.

Nusinovici, V., Crubille, C., Opolon, P., Touboul, J. P., Darnis, F., and Caroli, J. (1977). Hépatities fulminantes avec coma. Revue de 137 cas. II. Évolution et pronostic. Gastroenterologie Clinique et Biologique, 1, 875-886.

Opolon, P., Hecht, Y., Theodoropoulos, G., Hadchouel, P., Grynblat, A., and Caroli, J. (1969). Ictères graves par nécrose hépatique aiguë: étude clinique, biologique et anatomique de 48 cas. Revue Médico-Chirurgicale des Maladies du Foie, 44, 251-290.

Opolon, P., Lavallard, M. C., Crubille, C., Gateau, P., Nusinovici, V., Granger, A., Darnis, F., and Caroli, J. (1975). Encéphalopathie au cours de l'atrophie hépatique aiguë. Effet de l'épuration des moyennes molécules (résultats préliminaires). Nouvelle Presse Médicale, 4, 29872991.

Opolon, P., Lavallard, M. C., Huguet, C., Bidallier, M., Granger, A., Gallot, D., and Bloch, P. (1976a). Hemodialysis versus crosshemodialysis in experimental hepatic coma. Surgery, Gynecology and Obstetrics, 142, 845-854.

Opolon, P., Rapin, J. R., Huguet, C., Granger, A., Delorme, M. L., Boschat, M., and Sausse, A. (1976b). Hepatic failure coma (HFC) treated by polyacrylonitrile membrane (PAN) hemodialysis (HD). Transactions American Society for Artificial Internal Organs, 22, 701-710.

Record, C. O., Buxton, B., Chase, R. A., Curzon, G., Murray-Lyon, I. M., and Williams, R. (1976). Plasma and brain amino-acids in fulminant hepatic failure and their relationship to hepatic encephalopathy. European Journal of Clinical Investigation, 6, 387-394.

Rosen, H. M., Yoshimura, N., Hodgman, J. M., and Fischer, J. E. (1977). Plasma amino acid patterns in hepatic encephalopathy of differing etiology. Gastroenterology, 72, 483-487.

Rueff, B., and Benhamou, J. P. (1973). Acute hepatic necrosis and fulminant hepatic failure. Gut, 14, 805-815.

Rueff, B., Roche-Sicot, J., and Sicot, C. (1974). Traitement de l'insuffisance hépato-cellulaire aigne grave par circulation croisée. Méthodes et résultats. Annales de l'Anesthésiologie Française, 15, spec. 3, 249-254.

Saunders, S. J., Terblanche, J., Bosman, S. C. W., Harrison, G. G., Walls, R., Hickman, R., Biebuyck, J., Dent, D., Pearce, S., and Barnard, C. M. (1968). Acute hepatic coma treated by cross-circulation with a baboon and by repeated 
exchange transfusions. Lancet, 2, 585-588.

Sausse, A., Granger, A., Man, N. K., and Funck-Brentano, J. L. (1974). Un nouveau rein artificiel: nouvel appareil associant une membrane à haute perméabilité et un bain de dialyse en circuit fermé. Nouvelle Presse Médicale, 3, 957958.

Scotto, J., Opolon, P., Étévé, J., Vergoz, D., Thomas, M., and Caroli, J. (1973). Liver biopsy and prognosis in acute liver failure. Gut, 14, 927-933.

Sicot, C., Fréjaville, J. P., Roche, J., Rueff, B., Benhamou, J. P., and Fauvert, R. (1971). Six cas d'hépatite grave traitée par circulation croisée interhumaine. Annales de Médecine Interne, 122, 381-387.
Silk, D. B. A., Hanid, M. A., Trewby, P. N., Davies, M. Chase, R. A., Langley, P. G., Mellon, P. J., Wheeler, P. G., and Williams, R. (1977). Treatment of fulminant hepatic failure by polyacrylonitrile membrane haemodialysis. Lancet, 2, 1-3.

Silk, D. B. A., and Williams, R. (1978). Experiences in the treatment of fulminant hepatic failure by conservative therapy, charcoal haemoperfusion and polyacrylonitrile haemodialysis. International Journal of Artificial Organs, 1, 29-33.

Ware, A. J., D'Agostino, A. M., and Combes, B. (1971). Cerebral edema; a major complication of massive hepatic necrosis. Gastroenterology, 61, 877-884.

\section{The August 1978 Issue}

\section{THE AUGUST 1978 ISSUE CONTAINS THE FOLLOWING PAPERS}

Comparative clinical impact of endoscopic pancreatography, grey-scale ultrasonography, and computed tomography (EMI scanning) in pancreatic disease: preliminary report P. B. COTTON, M. E. DENYER, L. KREEL, J. HUSBAND, H. B. MEIRE, AND W. LEES

Computed tomography, ultrasound, and cholestatic jaundice A. I. MORRIS, R. A. FAWCITT, R. WOOD, W. S. C. FORBES, I. ISHERWOOD, AND M. N. MARSH

G cell population of the gastric antrum, plasma gastrin, and gastric acid secretion in patients with and without duodenal ulcer C. M. S. ROYSTON, JULIA POLAK, S. R. BLOOM, W. M. COOKE, R. C. G. RUSSELL, A. G. E. PEARSE, J. SPENCER, R. B. WELBOURN, AND J. H. BARON

Postprandial duodenal function in man L. J. MILLER, J.-R. MALAGELADA, AND V. L. W. GO

Analysis of the effects of food and of digestive secretions on the small intestine of the rat: III. Mucosal mass, activity of brush border enzymes, and in vivo absorption of galactose, sodium, and potassium R. ECKNAUER, G. FEYERABEND, AND H. RAFFLER

Transport of large breakdown products of dietary protein through the gut wall w. A. HEMMINGS AND E. W. WILLIAMS
Effect of dopamine infusion on gastric and pancreatic secretion and on gastrin release in man $R$. CALDARA, C. FERRARI, M. ROMUSSI, L. BIERTI, S. GANDINI, AND G. CURTARELLI

Factors which influenced postoperative complications in patients with ulcerative colitis or Crohn's disease of the colon on corticosteroids J. R. ALLSOP AND EMANOEL C. G. LEE

Acid microclimate in coeliac and Crohn's disease: a model for folate malabsorption M. L. LUCAS, B. T. COOPER, F. H. LEI, I. T. JOHNSON, G. K. T. HOLMES, J. A. BLAIR, AND W. T. COOKE

Prolyl hydroxylase activity in serum and rectal mucosa in inflammatory bowel disease M. J. G. FARTHING, A. P. DICK, G. HESLOP, AND C. I. LEVENE

Peliosis hepatis in recipients of renal transplants C. DEGOTT, B. RUEFF, H. KREIS, A. DUBOUST, F. POTET, AND J. P. BENHAMOU

Response of the skin in dermatitis herpetiformis to a gluten free diet, with reference to jejunal morphology B. T. COOPER, E. MALLAS, M. D. TROTTER, AND W. T. COOKE

Effect of colchicine and vinblastine on rat intestinal water transport and Na-K-ATPase activity D. RACHMILEWITZ, R. FOGEL, AND F. KARMELI

Notes and activities; Books

Copies are still available and may be obtained from the PUBLISHING MANAGER, BRTTISH MEDICAL ASSOCIATION, TAVISTOCK SQUARE, LONDON WC1H 9JR, price $£ 2 \cdot 75$, including postage 